\title{
Consumer Behavior Toward Nonlocal Brands
}

\author{
Sana Azar, Amina Talat, Feryal Khan, Anam Rana*
}

\begin{abstract}
This study explores consumer behavior toward nonlocal brands in Pakistan. Specifically, it examines the extent to which (i) product quality, (ii) country of origin, (iii) religiosity (in the context of Pakistan as a predominantly Muslim country), (iv) social status, and (v) the unavailability of local substitutes determine consumers' purchasing decisions. Consumer ethnocentrism and the desire to emulate economically developed country lifestyles serve as the study's moderating variables. The research data was collected through a questionnaire survey conducted in Lahore among a sample of 200 people between the ages of 18 and 55. The questionnaires were distributed via Google Docs and employed a convenience and snowball sample. A confirmatory factor analysis was carried out to establish reliability and validity. The structured model was then used to assess the relationships identified above.
\end{abstract}

Keywords: attitude toward nonlocal brands, quality, religious conviction, economically developed country lifestyles, consumer ethnocentrism.

JEL classification: M30, M31, M37.

\section{Introduction}

The number of farmers' markets has grown fourfold since the 1970s; this is attributed to consumers' preference for and the rising popularity of locally produced products (Williamson, 2014). A local example of such markets is the Khalis Market recently established in Lahore, Pakistan. Consumers' definition of "local" is determined by the product's proximity to home (Adams \& Adams, 2011). The literature also indicates, however, that consumers tend to prefer foreign (nonlocal) products (Phau, 2014). Given this contradiction, our study investigates the collective impact of different factors that influence consumer behavior toward brand origin. These include product quality, social status, the unavailability of local substitutes, religious conviction, the desire to emulate economically developed country (EDC) lifestyles, and consumer ethnocentrism.

\footnotetext{
* Senior teaching fellow, assistant professor, assistant professor, and research assistant, respectively, at the Lahore School of Economics.
} 
Specifically, we aim to understand consumer perceptions and attitudes toward nonlocal brands in an emerging economy and predominantly Muslim country such as Pakistan. In this context, we investigate whether the factors listed above affect consumers' preference for domestic over foreign products and vice versa. The research conducted on consumer behavior in developed countries suggests that, when consumers decide to purchase nonlocal products, their decision is based on product quality and worth. Our study examines whether this applies with reference to Pakistan.

\section{Literature Review}

The theoretical framework of this study is illustrated below and discussed in detail in this section.

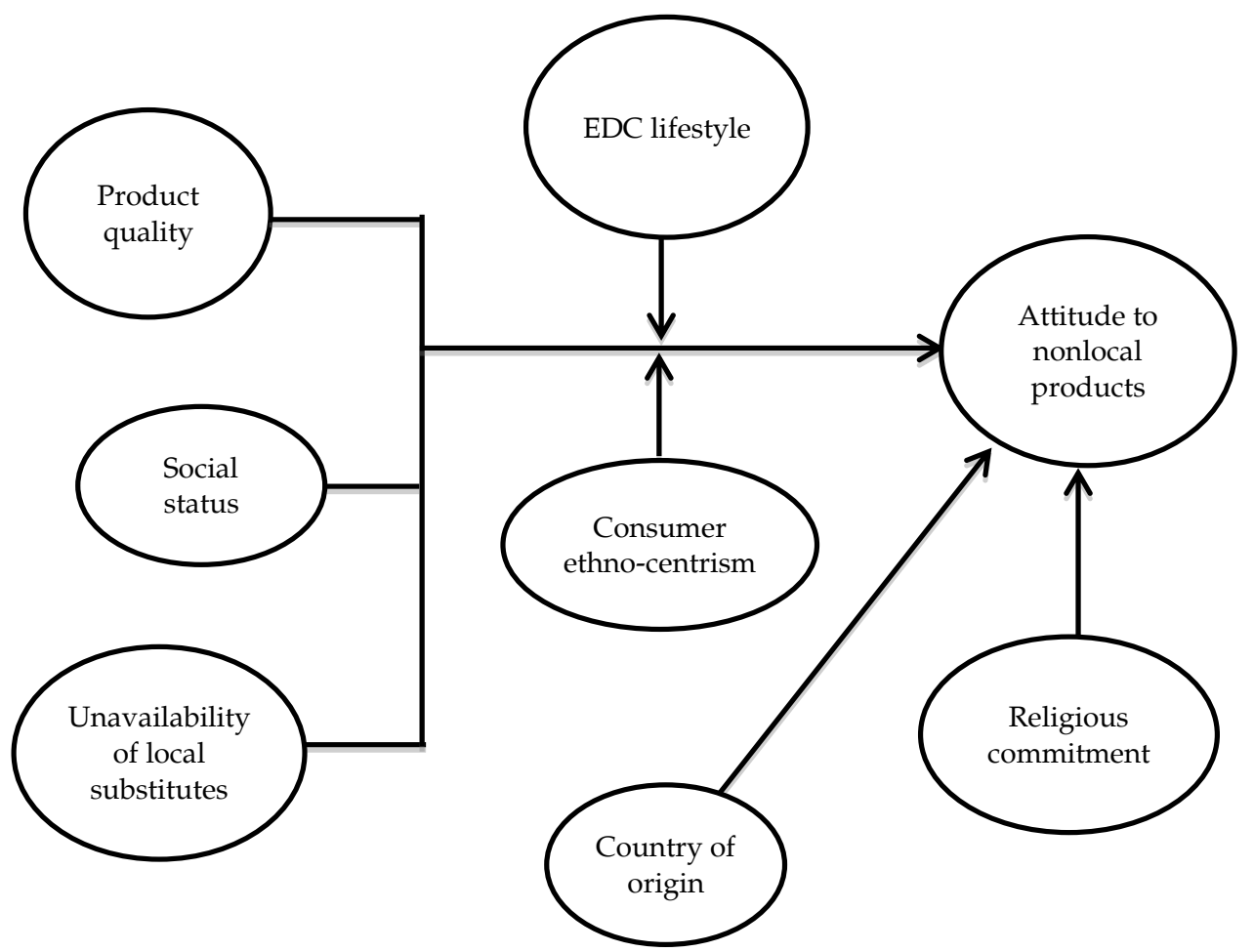

Schuiling and Kapferer (2004) argue that consumers are likely to be more aware of-and prefer-local brands relative to nonlocal brands. However, local brands are not as varied as their foreign equivalents and firms cannot always employ effective marketing strategies for local products in the global market, given that such products often cater to the local culture (Belk, Devinney, \& Eckhardt, 2005). Consumers classify and 
evaluate nonlocal brands under three main heads: (i) "quality signal," (ii) "global myth," and (iii) "social responsibility;" these factors determine their purchase decisions (Holt, Quelch, \& Taylor, 2004).

Johansson and Ronkainen (2005) find that consumers with a similar level of product knowledge associate nonlocal brands with greater prestige. Perceived product quality is defined as consumers' evaluation of brand dominance on the basis of intrinsic and extrinsic factors. Inherent factors include presentation and durability while extrinsic factors include brand name guarantee (Kirmani \& Baumgartner, 2000). Consumers may give more weight to nonlocal brands if they associate these with higher quality and prestige (Nguyen, Barrett, \& Miller, 2005; Steenkamp, Batra, \& Alden, 2003). Our first hypothesis (H1), therefore, is that product quality is positively related to consumer attitudes toward nonlocal products.

Perceived prestige, however, influences purchase decisions only to some degree as it varies with product type. Products that are visibly consumed or used in public, for instance, may be associated with a stronger consumer preference for nonlocal brands (Steenkamp \& Ter Hofstede, 2002). Steenkamp et al. (2003) argue that prestige is the second most significant factor to influence consumers' preference for nonlocal products. Generally, the literature finds that consumers prefer nonlocal brands that connote a higher social status (Schuiling \& Kapferer, 2004; Steenkamp et al., 2003; Shocker, Srivastava, \& Ruekert, 1994). Our second hypothesis $(\mathrm{H} 2)$, therefore, is that consumers prefer nonlocal products because they add to their social status.

In the case of nonlocal brands, the country of origin influences consumer behavior and preferences because it is related to product quality and social status and prestige (Kinra, 2006). Nonlocal brands may be considered prestigious if they are more expensive and less easily accessible than local brands or if they are associated with a certain desirable consumer image. The particular country of origin also matters: one study shows that Chinese consumers have a more positive perception of highly industrialized countries than of newly industrialized countries (Ahmed \& d'Astous, 2002). Developing country consumers may desire products from developed countries if they believe that these products are of better quality and reflect higher social status (Batra et al., 2000).

The country-of-origin effect contributes to consumers' impression of a particular brand, eventually affecting their purchase decision. A strong brand image may lead to rivalry, thereby increasing sales and directly affecting consumers' purchase decisions. Thus, both the brand producer 
and its country of origin can affect brand loyalty (Baldauf, Cravens, Diamantopoulos, \& Zeugner-Roth, 2009; Keller, 2003). Our third hypothesis (H3), therefore, is that a foreign brand's country of origin is associated with a positive consumer attitude toward nonlocal products.

Consumer ethnocentrism focuses on the dependability and ethics of purchasing foreign products along with the loyalty of consumers to locally manufactured products (Watson \& Wright, 2000; Shimp \& Sharma, 1987). Consumers tend to distinguish between local and nonlocal products and may avoid purchasing the latter out of patriotism (Shankarmahesh, 2006). The level of ethnocentrism varies from country to country. A study on Iran shows that ethnocentric consumers are not heavily exposed to nonlocal brands (Bahaee \& Pisani, 2009). Another study conducted in Lucknow in India reveals that, although consumers are highly ethnocentric, they are not biased against nonlocal brands (Kinra, 2006).

Lantz and Loeb (1996) investigate the value that North American consumers place on a given product (computer mouse pads) manufactured in their own or another country. They find that highly ethnocentric consumers are more likely to behave favorably toward products from culturally similar countries. Our fourth hypothesis (H4) is that consumer ethnocentrism moderates the relationship between (i) product quality, (ii) social status, and (iii) the availability of local products and consumers' attitude toward nonlocal products.

Religiosity can also influence consumer decision-making habits, performance, lifestyle, attitudes, and awareness (Jusmaliani \& Nasution, 2009). Religiosity is categorized as either intrapersonal or interpersonal, both of which play a crucial role in the lifestyles of orthodox consumers (Mokhlis \& Spartks, 2007). The first dimension reflects internal religious beliefs and character while the second includes external religious affiliations and practices. The literature suggests that it is not just a particular religion that affects consumer behavior, but also the strength of an individual's religion conviction (Mukhtar \& Butt, 2012). Our fifth hypothesis ( $\mathrm{H} 5)$ is that religious conviction is associated with negative consumer attitudes toward nonlocal products.

A New Zealand study on the unavailability of local substitutes suggests that, in such a situation, consumers prefer to buy products from countries that are ethnically similar to their own. This makes it very important for consumers to be aware of a product's country of origin (Watson \& Wright, 2000). Our sixth hypothesis (H6) is that the unavailability of local substitutes leads consumers to purchase nonlocal products. 
In their study on India, Batra et al. (2000) show that the desire to emulate EDC lifestyles may encourage consumers to buy brands produced in developed countries in order to reflect their social position. Our seventh hypothesis (H7) is that this desire to emulate a certain lifestyle moderates the relationship between product quality, social status, the unavailability of local products, and consumers' attitude toward nonlocal products.

\section{Methodology}

We have used a deductive approach in this study, employing empirical cross-sectional data to test the proposed theoretical framework. A combination of self-selection sampling and snowball sampling was used to reach a sufficient number of respondents. The survey questionnaire was distributed using Google Docs to collect and code the data efficiently and cost-effectively. The survey link was distributed via different social media. The usable sample comprised 134 consumers between the ages of 18 and 55 from Lahore. A confirmatory factor analysis (CFA) was conducted to test the model's reliability, validity, and fit. The hypothesized relationships were then tested using the structured model.

Eight latent variables were measured based on 29 questions, four of which were demographical while the rest were measured on a five-point Likert scale ranging from 1 ("strongly disagree") to 5 ("strongly agree"). The conceptual and operational definitions and composite reliability of each variable is as follows:

- Country of origin (or manufacture) can have a positive or negative influence on consumers' decision-making or subsequent behavior (Elliott \& Cameron, 1994). This was measured using 11 items from Anwar, Yasin, Iqbal, and Sajid (2013) with a composite reliability of 0.914 .

- Consumers' attitude toward nonlocal products is determined by "quality signal, global myth and social responsibility" (Holt et al., 2004) and was measured using two items from Ismail, Masood, and Tawab (2012) with a composite reliability of 0.687 .

- Religious conviction is defined as being "capable of influencing an individual cognitively and behaviorally" (Mokhlis \& Spartks, 2007). This was measured using two items from Ilyas, Hussain, and Usman (2011) with a composite reliability of 0.847.

- Product quality is defined as the "perceived quality" of a product, based on "consumers' judgment about an entity's (service's) overall 
excellence or superiority" (Zeithaml, 1988). This was measured using two items from Batra et al. (2000) with a composite reliability of 0.782 .

- Social status is defined as consumers' preference for global brands associated with greater prestige (Schuiling \& Kapferer, 2004; Shocker et al., 1994; Steenkamp et al., 2003). This was measured using two items from Batra et al. (2000) with a composite reliability of 0.812 .

- The unavailability of local substitutes relates to the context where "country-of-origin information becomes advantageous in case of unavailability of domestic substitutes for those who import from culturally similar countries" (Watson \& Wright, 2000). This was measured using two items from Batra et al. (2000) with a composite reliability of 0.953 .

- Consumer ethnocentrism is defined as consumers' beliefs concerning "the correctness, indeed ethics, of shopping [for] foreign products" (Shimp \& Sharma, 1987). This was measured using three items from Batra et al. (2000) with a composite reliability of 0.746 .

- The desire to emulate EDC lifestyles arises when "consumers' preferences are positively related to the economic development of the country of origin" and is based on the assumption that good quality connotes economic development (Lumpkin \& Crawford, 1985). This was measured using one item from Batra et al. (2000).

\section{Results and Analysis}

Using CFA, we evaluate the model based on several criteria, including uni-dimensionality, reliability, and convergent validity (Miller \& Luo, 2002; Anderson \& Gerbing, 1988). All the item factor loadings were greater than 0.4 on their corresponding constructs.

\subsection{Assessment of Model Fit}

The model's p-value is significant although the chi-squared statistics are susceptible to the size of the sample. The model is not, therefore, rejected based on the chi-squared statistics alone (Bagozzi \& Yi, 1988). The results in Table 1 indicate an adequate model fit. 
Table 1: Model fit

\begin{tabular}{ll}
\hline P-value & 0.000 \\
CMIN/DF & 1.900 \\
Goodness of fit (GFI) & 0.895 \\
Adjusted goodness of fit (AGFI) & 0.859 \\
Tucker-Lewis index (TLI) & 0.862 \\
Comparative fit index (CFI) & 0.892 \\
Root mean-squared error of approximation (RMSEA) & 0.082 \\
\hline
\end{tabular}

Source: Authors' calculations.

\subsection{Reliability and Validity}

Composite reliability (CR) represents the internal consistency of each factor. All the variables meet the approximate 0.70 cutoff recommended by Nunnally (1978). Table 2 shows that the CR values for the constructs range from 0.953 (unavailability of local substitutes) to 0.687 (attitude toward nonlocal products). Fornell and Larcker (1981) suggest that the average variance extracted (AVE) provides an indicator of the overall convergent validity. In this case, the AVE for each scale is close to or greater than the 0.50 threshold value (Rosenzweig \& Roth, 2007).

Table 2: Reliability and validity

\begin{tabular}{lccc}
\hline Variable & CR & AVE & Items \\
\hline Social status & 0.812 & 0.707 & 2 \\
Unavailability of local substitutes & 0.953 & 0.927 & 2 \\
Product quality & 0.782 & 0.651 & 2 \\
Country of origin & 0.914 & 0.483 & 11 \\
Religious conviction & 0.847 & 0.734 & 2 \\
Attitude toward nonlocal products & 0.687 & 0.528 & 2 \\
Consumer ethnocentrism & 0.746 & 0.551 & 3 \\
EDC lifestyle & - & - & 1 \\
\hline
\end{tabular}

Source: Authors' calculations.

\subsection{Path Analysis}

In order to test the structural relationships discussed above, we estimate their hypothesized causal paths; our findings support hypotheses H1 to H4 (Table 3). The relationship between attitude toward nonlocal 
products and product quality is highly significant (0.000) with a beta estimate of 0.469 . This implies that a one-unit change in quality will lead to a 0.469-unit change in consumer attitudes toward nonlocal products. Additionally, a one-unit change in religious conviction leads to a significant 0.39 -unit change in attitudes toward nonlocal products.

Table 3: Path analysis

\begin{tabular}{lccccc}
\hline Attitude & \multicolumn{1}{c}{ Variable } & Estimate & SE & CR & P \\
\hline $\begin{array}{l}\text { Attitude toward } \\
\text { nonlocal products }\end{array}$ & $\leftarrow$ Religious conviction & 0.039 & 0.068 & 0.576 & 0.021 \\
$\begin{array}{l}\text { Attitude toward } \\
\text { nonlocal products }\end{array}$ & $\leftarrow$ Country of origin & -0.105 & 0.077 & 1.353 & 0.176 \\
$\begin{array}{l}\text { Attitude toward } \\
\text { nonlocal products }\end{array}$ & $\leftarrow$ Product quality & 0.469 & 0.105 & 4.462 & $* * *$ \\
$\begin{array}{l}\text { Attitude toward } \\
\text { nonlocal products }\end{array}$ & $\leftarrow$ Unavailability of & 0.003 & 0.084 & 0.036 & 0.972 \\
$\begin{array}{l}\text { local substitutes } \\
\text { nttitude toward }\end{array}$ & $\leftarrow$ Social status & 0.129 & 0.179 & 0.723 & 0.469 \\
\hline
\end{tabular}

Source: Authors' calculations.

Based on our dataset, Table 3 indicates that two factors, religious conviction and product quality, determine attitudes toward nonlocal products. Contrary to the literature, our findings fail to support the impact of country of origin, the unavailability of local substitutes, and social status.

\subsection{Moderation}

In this section, we test the two moderating variables: (i) the desire to emulate EDC lifestyles and (ii) consumer ethnocentrism. Table 4 shows that higher levels of consumer ethnocentrism moderate the relationship between product quality and attitudes toward nonlocal products. The estimate of 0.704 is highly significant, with a p-value of less than 0.05, which implies that a one-unit change in quality will have a 0.704-unit change in attitudes toward nonlocal products. This finding underscores the argument that consumers with a higher level of ethnocentrism tend to avoid buying nonlocal products because they feel it is unpatriotic and may create local unemployment (Shimp \& Sharma, 1987). 
Table 4: Moderator 1: Consumer ethnocentrism

\begin{tabular}{|c|c|c|c|c|c|}
\hline $\begin{array}{l}\text { Consumer } \\
\text { ethnocentrism }\end{array}$ & Variable & Estimate & SE & CR & $\mathbf{P}$ \\
\hline \multicolumn{6}{|l|}{ High level } \\
\hline $\begin{array}{l}\text { Attitude toward } \\
\text { nonlocal products }\end{array}$ & $\leftarrow$ Product quality & 0.704 & 0.159 & 4.428 & $* * *$ \\
\hline $\begin{array}{l}\text { Attitude toward } \\
\text { nonlocal products }\end{array}$ & $\leftarrow \quad \begin{array}{l}\text { Unavailability of } \\
\text { local substitutes }\end{array}$ & -0.083 & 0.117 & -0.711 & 0.477 \\
\hline $\begin{array}{l}\text { Attitude toward } \\
\text { nonlocal products }\end{array}$ & $\leftarrow \quad$ Social status & 0.165 & 0.254 & 0.649 & 0.516 \\
\hline \multicolumn{6}{|l|}{ Low level } \\
\hline $\begin{array}{l}\text { Attitude toward } \\
\text { nonlocal products }\end{array}$ & $\leftarrow$ Product quality & 0.237 & 0.133 & 1.784 & 0.074 \\
\hline $\begin{array}{l}\text { Attitude toward } \\
\text { nonlocal products }\end{array}$ & $\leftarrow \quad \begin{array}{l}\text { Unavailability of } \\
\text { local substitutes }\end{array}$ & 0.003 & 0.116 & 0.023 & 0.982 \\
\hline $\begin{array}{l}\text { Attitude toward } \\
\text { nonlocal products }\end{array}$ & $\leftarrow \quad$ Social status & 0.088 & 0.248 & 0.354 & 0.723 \\
\hline
\end{tabular}

Source: Authors' calculations.

Table 5 shows that respondents with less desire to emulate EDC lifestyles ("low desire for product") significantly moderate the relationship between brand quality and attitudes toward nonlocal brands. A unit change in the quality of the product will lead to a 0.665 -unit change in consumer attitudes toward the product. The literature supports consumers' preference for brands produced by economically advanced countries based on the assumption that these products are of better quality (Lumpkin \& Crawford, 1985).

Table 5: Moderator 2: Desire for EDC lifestyle

\begin{tabular}{|c|c|c|c|c|c|c|}
\hline Desire for product & & Variable & Estimate & SE & CR & $\mathbf{P}$ \\
\hline \multicolumn{7}{|l|}{ Low } \\
\hline $\begin{array}{l}\text { Attitude toward } \\
\text { nonlocal products }\end{array}$ & $\leftarrow$ & Product quality & 0.665 & 0.159 & 4.191 & $* * *$ \\
\hline $\begin{array}{l}\text { Attitude toward } \\
\text { nonlocal products }\end{array}$ & $\leftarrow$ & $\begin{array}{l}\text { Unavailability of } \\
\text { local substitutes }\end{array}$ & -0.105 & 0.097 & -1.085 & 0.278 \\
\hline $\begin{array}{l}\text { Attitude toward } \\
\text { nonlocal products }\end{array}$ & $\leftarrow$ & Social status & -0.060 & 0.185 & -0.324 & 0.746 \\
\hline \multicolumn{7}{|l|}{ High } \\
\hline $\begin{array}{l}\text { Attitude toward } \\
\text { nonlocal products }\end{array}$ & $\leftarrow$ & Product quality & 0.282 & 0.124 & 2.277 & 0.053 \\
\hline
\end{tabular}




\begin{tabular}{lccccc}
\hline Desire for product & \multicolumn{1}{c}{ Variable } & Estimate & SE & CR & P \\
\hline $\begin{array}{l}\text { Attitude toward } \\
\text { nonlocal products }\end{array}$ & $\leftarrow \begin{array}{l}\text { Unavailability of } \\
\text { local substitutes } \\
\begin{array}{l}\text { Attitude toward } \\
\text { nonlocal products }\end{array}\end{array}$ & 0.005 & 0.117 & 0.046 & 0.963 \\
\hline
\end{tabular}

Source: Authors' calculations.

\section{Discussion and Conclusion}

The aim of this study was to add to the existing literature on consumer behavior in developing countries with respect to attitudes toward nonlocal products. It has contributed to the literature on consumer behavior toward nonlocal products in Pakistan by employing two moderating variables: the desire to emulate EDC lifestyles and consumer ethnocentrism.

We find that perceived quality has a significant and positive impact on attitudes toward nonlocal products. This finding supports the literature: consumers place a higher value on nonlocal brands because they assume that these brands are of better quality and carry greater prestige (Nguyen et al., 2005; Steenkamp et al., 2003). Social status does not appear to have a significant impact on attitudes toward nonlocal products. This may be because some consumers associate local products with greater prestige than nonlocal products (de Mooij \& Bovenberg, 1998). Local brands tend to reflect local cultural values and represent genuineness and social standing (Ger \& Belk, 1999).

Our findings point to an inverse relationship between country of origin and attitudes toward nonlocal products. A probable reason for this is that cultural dimensions such as individualism and socialism also influence the country-of-origin effect on attitudes toward nonlocal products (Gürhan-Canli \& Maheswaran, 2000), which we have not included in this study. The negative relationship between religious conviction and attitudes toward nonlocal products indicates that many consumers are likely to avoid buying nonlocal brands out of a strong sense of religiosity. Moreover, this will vary depending on the strength of the consumer's religious conviction (Mukhtar \& Butt, 2012).

We find that consumers with a higher level of ethnocentrism moderate the relationship between the quality of a product and attitudes toward nonlocal products. The relationship is highly significant when conducting the statistical analysis on AMOS. The literature supports this 
finding based on the argument that ethnocentric consumers avoid buying nonlocal products out of a sense of patriotism and the belief that such products affect opportunities for local employment (Shimp \& Sharma, 1987).

Consumers with less desire to emulate EDC lifestyles moderate the relationship between the quality of a product and attitudes toward nonlocal products. This relationship is highly significant and consistent with studies that find that consumers prefer to buy products produced by economically advanced countries because they feel such products are of better quality (Lumpkin \& Crawford, 1985).

Our findings are, however, limited by the representativeness of the sample used. The study was conducted in Lahore using convenience and snowball sampling methods, which implies that its findings cannot be generalized across Pakistan. Future research on this subject could, therefore, take into account not just the culture of the society being studied, but also cross-cultural comparisons of consumer behavior. Additionally, while we have employed cross-sectional data and examined causal factors with hypotheses based on individuals' self-reported opinions about their consumption behavior, future research could use a combination of different methodologies (quantitative and qualitative) and more objective methods of data collection, such as experiments.

A key implication of this study is that multinational firms should initiate cooperative ventures with domestic firms or set up overseas subsidiaries to regulate the impact of ethnocentricity, which is important to manage. Marketers in Pakistan should emphasize the quality of their products in order to remain competitive in relation to global companies operating in local markets. Managers and marketers should also be aware of how strong a role religious conviction might play in consumer behavior toward their products (see Mokhlis \& Spartks, 2007; Khraim, 2010). 


\section{References}

Adams, D. C., \& Adams, A. E. (2011). De-placing local at the farmers' market: Consumer conceptions of local foods. Journal of Rural Social Sciences, 26(2), 74-100.

Ahmed, S., \& d'Astous, A. (2002). Southeast Asian consumer perceptions of countries of origin: The case of automobiles and videocassette recorders. Journal of Asia Pacific Marketing, 1(1), 19-41.

Aldridge, S., \& Rowley, J. (1998). Measuring customer satisfaction in higher education. Quality Assurance in Education, 6(4), 197-204.

Anderson, J. C., \& Gerbing, D. W. (1988). Structural equation modeling in practice: A review and recommended two-step approach. Psychological Bulletin, 103(3), 411-423.

Anwar, S., Yasin, S., Iqbal, A., \& Sajid, M. (2013). Demographic and geographic influence of the country-of-origin image on consumer purchase decision. European Journal of Business and Management, 5(8), 199-209.

Bagozzi, R. P., \& Yi, Y. (1988). On the evaluation of structural equation models. Journal of the Academy of Marketing Science, 16, 74-94.

Bahaee, M., \& Pisani, M. J. (2009). Iranian consumer animosity and US products: A witch's brew or elixir? International Business Review, 18(2), 199-210.

Baldauf, A., Cravens, K. S., Diamantopoulos, A., \& Zeugner-Roth, K. P. (2009). The impact of product-country image and marketing efforts on retailer-perceived brand equity: An empirical analysis. Journal of Retailing, 85(4), 437-452.

Batra, R., Ramaswamy, V., Alden, D. L., Steenkamp, J.-B. E., \& Ramachander, S. (2000). Effects of brand local and nonlocal origin on consumer attitudes in developing countries. Journal of Consumer Psychology, 9(2), 83-95.

Belk, R. W., Devinney, T., \& Eckhardt, G. (2005). Consumer ethics across cultures. Consumption, Markets and Culture, 8(3), 275-289. 
de Mooij, R. A., \& Bovenberg, A. L. (1998). Environmental taxes, international capital mobility and inefficient tax systems: Tax burden vs. tax shifting. International Tax and Public Finance, 5(1), 7-39.

Elliott, G. R., \& Cameron, R. C. (1994). Consumer perception of product quality and the country-of-origin effect. Journal of International Marketing, 2(2), 49-62.

Fornell, C., \& Larcker, D. F. (1981). Evaluating structural equation models with unobservable variables and measurement error. Journal of Marketing Research, 18, 39-50.

Ger, G., \& Belk, R. W. (1999). Accounting for materialism in four cultures. Journal of Material Culture, 4(2), 183-204.

Gürhan-Canli, Z., \& Maheswaran, D. (2000). Cultural variations in country of origin effects. Journal of Marketing Research, 37(3), 309-317.

Holt, D. B., Quelch, J., \& Taylor, E. L. (2004). How global brands compete. Harvard Business Review, 82(9), 68-75.

Ilyas, S., Hussain, M. F., \& Usman, M. (2011). An integrative framework for consumer behavior: Evidence from Pakistan. International Journal of Business and Management, 6(4), 120-128.

Ismail, Z., Masood, S., \& Tawab, Z. M. (2012). Factors affecting consumer preference of international brands over local brands. International Proceedings of Economics Development and Research, 31, 54-59.

Johansson, J. K., \& Ronkainen, I. A. (2005). The esteem of global brands. Journal of Brand Management, 12(5), 339-354.

Jusmaliani \& Nasution, H. (2009). Religiosity aspect in consumer behavior: Determinants of halal meat consumption. ASEAN Marketing Journal, 1(2), 1-11.

Keller, K. L. (2003). Brand synthesis: The multidimensionality of brand knowledge. Journal of Consumer Research, 29(4), 595-600.

Khraim, H. (2010). Measuring religiosity in consumer research from an Islamic perspective. Journal of Economic and Administrative Sciences, 26(1), 52-78. 
Kinra, N. (2006). The effect of country-of-origin on foreign brand names in the Indian market. Marketing Intelligence and Planning, 24(1), 15-30.

Kirmani, A., \& Baumgartner, H. (2000). Reference points used in quality and value judgments. Marketing Letters, 11(4), 299-310.

Lantz, G., \& Loeb, S. (1996). Country of origin and ethnocentrism: An analysis of Canadian and American preferences using social identity theory. Advances in Consumer Research, 23, 374-378.

Lumpkin, J. R., \& Crawford, J. C. (1985). Consumer perceptions of developing countries. In N. K. Malhotra (Ed.), Developments in marketing science: Proceedings of the Academy of Marketing Science (vol. 8, pp. 95-107). Coral Gables, FL: Academy of Marketing Science.

Miller, M. W., \& Luo, J. (2002). Effects of ethanol and transforming growth factor beta (TGF beta) on neuronal proliferation and nCAM expression. Alcoholism: Clinical and Experimental Research, 26(8), 1281-1285.

Mokhlis, S., \& Spartks, L. (2007). Consumer religiosity and shopping behavior in Kuala Lumpur. Malaysian Management Journal, 11(1-2), 87-101.

Mukhtar, A., \& Butt, M. M. (2012). Intention to choose halal products: The role of religiosity. Journal of Islamic Marketing, 3(2), 108-120.

Nguyen, T., Barrett, N., \& Miller, K. (2005, May). Perceived brand globalness: Antecedents and outcome - the case of Vietnamese consumers. Paper presented at the 34th EMAC Conference, Università Commerciale Luigi Bocconi, Milan, Italy.

Nunnally, J. C. (1978). Psychometric theory (2nd ed.). New York, NY: McGraw-Hill.

Phau, I. (2014). "Domestic-made" or "foreign-made" luxury brands? In T.-M. Choi (Ed.), Fashion branding and consumer behaviors (pp. 77100). New York, NY: Springer.

Rosenzweig, E. D., \& Roth, A. V. (2007). B2B seller competence: Construct development and measurement using a supply chain strategy lens. Journal of Operations Management, 25, 1311-1331. 
Schuiling, I., \& Kapferer, J.-N. (2004). Executive insights: Real differences between local and international brands: Strategic implications for international marketers. Journal of International Marketing, 12(4), 97-112.

Schuiling, I., \& Lambin, J.-J. (2003). Do global brands benefit from a unique worldwide image? Symphonya: Emerging Issues in Management, 2, 17-26.

Shankarmahesh, M. N. (2006). Consumer ethnocentrism: An integrative review of its antecedents and consequences. International Marketing Review, 23(2), 146-172.

Shimp, T. A., \& Sharma, S. (1987). Consumer ethnocentrism: Construction and validation of the CETSCALE. Journal of Marketing Research, 24(3), 280-290.

Shocker, A. D., Srivastava, R. K., \& Ruekert, R. W. (1994). Challenges and opportunities facing brand management: An introduction to the special issue. Journal of Marketing Research, 31(2), 149-158.

Steenkamp J.-B. E., Batra R., \& Alden D. L. (2003). How perceived globalness creates brand value. Journal of International Business Studies, 34, 53-65.

Steenkamp, J.-B. E., \& Ter Hofstede, F. (2002). International market segmentation: Issues and perspectives. International Journal of Research in Marketing, 19(3), 185-213.

Watson, J. J., \& Wright, K. (2000). Consumer ethnocentrism and attitudes toward domestic and foreign products. European Journal of Marketing, 34(9-10), 1149-1166.

Williamson, S. (2014). A multivariate analysis of consumers' beliefs, attitudes, and behaviors associated with locally produced food and farmers' market patronage. Unpublished Master's thesis, University of Kentucky, Lexington, $\mathrm{KY}$.

Zeithaml, V. A. (1988). Consumer perceptions of price, quality, and value: A means-end model and synthesis of evidence. Journal of Marketing, 52(3), 2-22. 


\section{Appendix}

\section{Questionnaire}

Items 5 to 28 were measured on a Likert scale of 1 ("strongly disagree") to 5 ("strongly agree").

1. Gender

2. Age

3. Level of education

4. Do you use international brand products?

5. If an international brand product and a national brand product cost the same, would you prefer the international brand product?

6. People buy international brand products in order to be accepted by a particular social group. Do you agree?

7. Do you buy foreign products in order to be accepted by a particular social group?

8. Overall, how would you rate the quality of foreign brands?

9. Do you think foreign brands are of better quality than local brands?

10. Are all the brands you consume easily available for purchase?

11. Have you seen advertisements in Pakistan (magazines, radio, or TV) for all the brands you consume?

12. Are you always aware of a product's country of origin?

13. When many equivalent products (e.g., Sony, Panasonic) are available, do you prioritize your purchases on the basis of country of origin?

14. Would you refuse to purchase a product without knowing its country of origin?

15. When purchasing a product, do you believe that the country of origin determines the product's technological aspects?

16. Do you firmly believe that the country of origin determines the quality of a product?

17. Country of origin reduces the search for products. Do you agree? 
18. When purchasing a new product for which you do not have sufficient information, do you purchase the product on the basis of its country of origin?

19. When purchasing an automobile, do you always try and determine its country of origin?

20. When purchasing a TV, do you always try and determine its country of origin?

21. When purchasing a mobile telephone, do you always try and determine its country of origin?

22. When purchasing cosmetics, do you always try and determine their country of origin?

23. Do you feel pleasure and satisfaction in following Islamic teachings?

24. Do you feel pleasure in seeing others follow Islamic teachings?

25. To what extent do you admire the lifestyles of people living in economically developed countries, such as the US or in Western Europe?

26. Purchasing foreign products is un-Pakistani. Do you agree or disagree?

27. Pakistanis should not buy foreign products because it hurts local businesses and causes unemployment. A real Pakistani should always buy Pakistani-made products. Do you agree or disagree?

28. It is not right to purchase foreign products. Do you agree or disagree? 